\title{
An analysis of Market Arrival and Price Behavior of Potato in India
}

\author{
Sreepriya P. ${ }^{1 *}$ and J.S. Sidhu ${ }^{2}$ \\ ${ }^{1}$ Department of Agricultural Economics, Tamil Nadu Agricultural University, Coimbatore, Tamil Nadu, India \\ ${ }^{2}$ Department of Economics and Sociology, Punjab Agricultural University, Ludhiana, Punjab, India \\ *Corresponding author: sreepriya.padmaja@gmail.com (ORCID ID: 0000-0001-7781-0181)
}

Received: 03-09-2019

Revised: $13-01-2020$

Accepted: 24-02-2020

\begin{abstract}
Potato is an integral part of the global food system and the world's number one non food grain commodity. During 2018-19 potato acreage in India was 21.84 lakh ha with a production of 52.58 million tonnes. Major potato growing states are Uttar Pradesh, West Bengal, Bihar, Gujarat, Madhya Pradesh and Punjab. Prices of potato exhibit both inter-year and intra-year variations. This price fluctuation in potato is a major concern among farmers, consumers and policy makers. The current study is an attempt to analyze the behavior of prices and arrivals of potato in the major markets of India. The time series data on the price and arrivals of potato in the major markets of leading producing states were collected from Agmarknet. The data corresponding to the potato prices in future market were collected from MCX (Multi Commodity Exchange of India Ltd.) where it has been traded till 2014. The prices of potato significantly increased over the last ten years compounded annually in all the selected markets. Significant positive growth rate of arrivals was found in Agra and Ahmadabad markets and negative growth rate was found in Jalandhar market. The price and arrivals series have shown significant negative correlation in all the markets. Seasonal indices depict that prices of potato are usually high during the months of October to December and starts declining till April which is in par with the post harvest period of the crop. Price discovery of potato is a complex process and is affected by a number of factors like production, total arrivals, lagged price, future prices, which have been quantified here and other factors like transportation, storage, weather uncertainties and pests and disease attack.

\section{Highlights}

(0 There is huge inter and intra year instability in the prices of potato in India

( Price discovery of potato is affected by a number of factors like production, total arrivals, lagged price, future prices
\end{abstract}

Keywords: Price behavior, arrivals, prices, potato, seasonality

Potato is an integral part of the global food system and the world's number one non food grain commodity. The crop plays an important role in ensuring food security of present and future generation. Keeping in view the potential of potato in the food security of developing nations, FAO has rightly declared it as 'Future Food Crop'. Considering its importance, United Nations (UN) had declared 2008 as the International Year of Potato. Globally India stands third in terms of area and second in terms of production (52.58 million tonnes) after China. During 2018-19 potato acreage in India was 21.84 lakh ha with a production of 52.58 million tonnes (Indiastat, 2019). Major potato growing states are Uttar Pradesh (30\%), West Bengal (24.31\%), Bihar (14.15\%), Gujarat (7.31\%), Madhya Pradesh (6.30\%) and Punjab (5.17\%) (Indiastat, 2019).

How to cite this article: Sreepriya, P. and Sidhu, J.S. (2020). An analysis of market arrival and price behavior of potato in India. Economic Affairs, 65(1): 09-15. 
AESSRA

Sreepriya and Sidhu

Prices of potato exhibit both inter-year and intrayear variations. The seasonal variations are caused by changes in area under cultivation in the major growing areas, unexpected weather conditions or outbreak of pests or diseases, price of other vegetables, demand of potato from the major cities and food processing industries, seasonality, transportation charges from one place to another, hoarding, regional concentration of cold storage facilities etc. Harvesting season in important potato producing states in the country comes in between November- December to March-April. Total arrivals of the crop during the year determine to a large extend the intra-year seasonality of prices of potato. Prices of potato starts increasing from April as harvesting season comes to an end in most of the producing centres. During peak arrival period, farmers and traders store potatoes in cold stores in anticipation of selling at higher prices during lean season of April-November. This price fluctuation in potato is a major concern among farmers, consumers and policy makers. The timely and reliable market intelligence is yet to come up to the expectations to meet the growing needs of the potato economy. Market intelligence on aspects like potential markets, pattern of market arrivals and prices in important regional and national markets in different months of a year assumes major significance as the potato production is spread across many states in India (Kumar et al. 2006). The current study is an attempt to analyze the behavior of prices and arrivals of potato in the major markets of India.

\section{MATERIALS AND METHODS}

\section{Data Collection}

The study was undertaken on a macro framework based on secondary data from the leading potato producing states of India i.e., Uttar Pradesh, West Bengal, Bihar, Madhya Pradesh, Punjab and Gujarat. Agra, Burdwan, Patna, Indore, Jalandhar and Ahmadabad were the markets selected from these states respectively for the study. The data on the price and arrivals of potato in the major markets of leading producing states were collected from Agmarknet. The data corresponding to the potato prices in future market were collected from MCX (Multi Commodity Exchange of India Ltd.) where it has been traded till 2014.

\section{Trend analysis}

Growth trends for the price series and the arrivals were also worked out using the monthly wholesale price and arrivals data from 2005 to 2014,

$$
Y=a e^{b t}
$$

Or $\operatorname{Ln} Y=\operatorname{Ln} a+b t$

Where, $\operatorname{Ln} Y=$ Real price, arrivals

$$
\begin{aligned}
& t=\text { Time (Years) } \\
& a=\text { intercept } \\
& b=\text { growth rate to be estimated }
\end{aligned}
$$

Intra year trend in prices and arrivals of potato was analyzed by working out the seasonal indices by using twelve year centered moving averages.

\section{Relation between market arrivals and prices}

The relation between market arrivals and prices of potato in the major potato producing states was analyzed using Karl Pearson correlation coefficient using monthly data from 2005 to 2014 . The degree of relationship for different years was studied.

The correlation coefficient has been computed using the following formula,

$$
r x y=\frac{\operatorname{Cov}(x, y)}{\sqrt{\operatorname{Var}(x) \cdot \operatorname{Var}(y)}}
$$

\section{Factors influencing price of potato}

The variation in the prices of potato is caused by a number of factors. To investigate the factors determining the prices of potato in India, multiple regression analysis using linear equation was carried out using time series data of variables from 2006 to 2014. Yearly data of prices and arrivals were used for the analysis.

$$
Y_{1}=a+b_{1} x_{1}+b_{3} x_{2}+b_{4} x_{3}+\ldots . .+b_{n} x_{n}+u_{2}
$$

Where,

$$
\begin{aligned}
& Y_{1}=\text { Prices of potato } \\
& a=\text { Constant terms } \\
& u=\text { Error term } \\
& b_{1}, b_{2^{\prime}}, b_{3} \ldots b_{n}=\text { Coefficients of different explanatory } \\
& \text { variables. }
\end{aligned}
$$


$x_{1}, x_{2}, x_{3} \ldots x_{n}=$ Explanatory variables i.e.

$x_{1}=$ Production of potato,

$x_{2}=$ lagged prices of potato

$x_{3}=$ Future prices of potato

$x_{4}=$ Arrivals of potato

\section{RESULTS AND DISCUSSION}

Potato like other agricultural commodities is seasonal. Accordingly, its arrivals in markets vary over the months. Cold storage operations of potato also determine the pattern of arrivals which is ultimately reflected with the pattern of its prices. The trends in these behaviors of arrivals and prices were examined and presented in this section.

Analysis of trend component in price series involves ascertaining the general direction of movement of prices over several years. Simple regression models like linear regression model, quadratic regression model and exponential regression model were tried. Considering the multiple regression coefficient and standard error, exponential regression model was found to be best and hence the results of the same were considered for discussion. Compound growth rates of arrivals and prices and prices of potato were also calculated.

Overall, the prices of potato significantly increased over the last ten years compounded annually in all the selected markets. The prices exhibited significant positive exponential trend over the years. Prices in Agra market have shown highest growth rate $(11.50 \%)$ followed by Ahmadabad $(10.50 \%)$, Patna $(9.70 \%)$, Indore $(9.0 \%)$, Burdwan $(8.90 \%)$ followed by Jalandhar (6.10\%).

Positive exponential trend in the arrivals of potato was seen in Agra, Patna, Indore and Ahmadabad. Significant growth rate of 49 per cent in the arrivals of potato was seen in Agra market followed by 3.50 per cent in Ahmadabad market. A significant negative growth rate of 7.20 per cent was seen in Jalandhar market. Burdwan market also showed negative growth rate in potato arrivals during the ten year period.

The phenomenon of inverse relationship between market arrivals and prices is well known in agricultural commodities. Nevertheless, factors like availability of cold storage facilities, the increased opportunities for export and import of these commodities due to trade liberalization, the value-addition through agro-processing etc not only weaken this negative relationship, but also in many cases, may turn it positive. This is more true for potato as it uses about 80 percent of total cold storage facilities that exist in our country (Khurana et al, 2002). The degree of relationship for different years from 2005 to 2014 was studied by computing correlation coefficients between market arrivals and prices of potato as shown in Table 2 .

It can be observed from the table that most of the time period considered, the price and arrivals series

Table 1: Trend component in prices and arrivals of potato (₹/ton) in potato markets

\begin{tabular}{|c|c|c|c|c|c|c|}
\hline \multicolumn{7}{|c|}{ Prices } \\
\hline Month & Intercept & Coefficient & $\mathrm{t}$-value & SE & $\mathbf{R}^{2}$ & CAGR (\%) \\
\hline Agra & 3202.53 & 0.11 & 2.23 & 0.32 & 0.55 & $11.50^{* * *}$ \\
\hline Patna & 4201.77 & 0.09 & 2.79 & 0.30 & 0.49 & $9.70^{* *}$ \\
\hline Burdwan & 4129.27 & 0.09 & 2.05 & 0.38 & 0.35 & $8.90^{*}$ \\
\hline Indore & 4095.18 & 0.08 & 3.844 & 0.2 & 0.649 & $9.0^{*}$ \\
\hline Jalandhar & 3242.33 & 0.06 & 1.57 & 0.34 & 0.24 & 6.10(NS) \\
\hline Ahmadabad & 4950.40 & 0.10 & 5.20 & 0.17 & 0.78 & $10.50^{* * *}$ \\
\hline \multicolumn{7}{|c|}{ Arrivals } \\
\hline Agra & 21267.50 & 0.34 & 3.35 & 0.36 & 0.67 & $49.00^{* * *}$ \\
\hline Patna & 997.50 & 0.02 & 0.27 & 0.60 & 0.01 & $1.80(\mathrm{NS})$ \\
\hline Burdwan & 121403.20 & -0.06 & -2.39 & 0.32 & 0.29 & $-6.20(\mathrm{NS})$ \\
\hline Indore & 52991.07 & 0.04 & 1.19 & 0.274 & 0.15 & 3.60(NS) \\
\hline Jalandhar & 55658.60 & -0.08 & -2.09 & 0.33 & 0.35 & $-7.20^{* *}$ \\
\hline Ahmadabad & 141688.00 & 0.04 & 2.64 & 0.09 & 0.47 & $3.50^{* *}$ \\
\hline
\end{tabular}

***-significant at $1 \%$ level ${ }^{* *}$-significant at $5 \%,{ }^{*}$-significant at $10 \%$. 


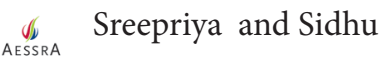

Table 2: Relationship between Market Arrivals and Wholesale Prices of Potato in major potato markets in India from 2005-2014-Correlation Coefficients

\begin{tabular}{lllllll}
\hline Year & Agra & Patna & Burdwan & Indore & Jalandar & Ahmadabad \\
\hline $\mathbf{2 0 0 5}$ & $-0.68^{* *}$ & -0.27 & $-0.56^{*}$ & $-0.66^{* *}$ & 0.12 & -0.11 \\
$\mathbf{2 0 0 6}$ & 0.19 & $0.80^{* * *}$ & $-0.82^{* * *}$ & $-0.64^{* *}$ & $-0.76^{* * *}$ & -0.05 \\
$\mathbf{2 0 0 7}$ & 0.03 & 0.23 & -0.38 & -0.50 & $-0.66^{* *}$ & -0.38 \\
$\mathbf{2 0 0 8}$ & $-0.534^{*}$ & 0.50 & -0.06 & -0.24 & 0.01 & -0.30 \\
$\mathbf{2 0 0 9}$ & $-0.70^{* *}$ & $-0.67^{* *}$ & -0.40 & $-0.76^{* * *}$ & -0.43 & -0.30 \\
$\mathbf{2 0 1 0}$ & $-0.94^{* * *}$ & 0.37 & $-0.68^{* *}$ & 0.03 & -0.09 & 0.20 \\
$\mathbf{2 0 1 1}$ & 0.10 & 0.26 & 0.01 & 0.50 & -0.24 & -0.47 \\
$\mathbf{2 0 1 2}$ & 0.11 & $-0.58^{*}$ & -0.12 & $-0.84^{* * *}$ & -0.37 & $-0.58^{* *}$ \\
$\mathbf{2 0 1 3}$ & $-0.90^{* * *}$ & $0.79^{* * *}$ & $-0.55^{*}$ & 0.07 & -0.17 & 0.12 \\
$\mathbf{2 0 1 4}$ & $-0.68^{* *}$ & -0.30 & -0.45 & $-0.80^{* * *}$ & -0.39 & -0.05 \\
\hline
\end{tabular}

***-significant at $1 \%$ level ${ }^{* *}$-significant at $5 \%,{ }^{*}$-significant at $10 \%$.

Table 3: Seasonal Indices of arrivals and prices of potato in Ahmadabad market from 2005 through 2014

\begin{tabular}{|c|c|c|c|c|c|c|}
\hline Month & Agra & Patna & Burdwan & Indore & Jalandar & Ahamadabad \\
\hline \multicolumn{7}{|c|}{ Arrivals } \\
\hline January & 134.30 & 170.00 & 78.00 & 124.75 & 142.41 & 143.45 \\
\hline February & 116.35 & 78.00 & 103.00 & 196.82 & 126.26 & 103.77 \\
\hline March & 116.98 & 67.00 & 290.00 & 160.47 & 132.65 & 125.66 \\
\hline April & 118.54 & 71.00 & 265.00 & 130.32 & 119.99 & 102.72 \\
\hline May & 96.03 & 74.80 & 79.20 & 82.38 & 67.69 & 80.48 \\
\hline June & 87.38 & 92.00 & 35.16 & 77.03 & 46.85 & 75.60 \\
\hline July & 81.67 & 96.00 & 21.19 & 90.59 & 60.33 & 78.90 \\
\hline August & 89.89 & 108.70 & 18.21 & 59.35 & 56.37 & 79.87 \\
\hline September & 89.96 & 90.00 & 25.25 & 51.34 & 51.97 & 74.36 \\
\hline October & 83.22 & 84.00 & 44.28 & 55.73 & 62.89 & 84.62 \\
\hline November & 84.24 & 105.00 & 32.00 & 71.91 & 137.44 & 96.16 \\
\hline December & 101.39 & 161.00 & 25.75 & 99.27 & 195.33 & 154.63 \\
\hline \multicolumn{7}{|c|}{ Prices } \\
\hline January & 66.17 & 77.00 & 72.00 & 85.89 & 73.18 & 82.36 \\
\hline February & 65.21 & 68.70 & 62.00 & 82.81 & 71.93 & 74.61 \\
\hline March & 77.33 & 77.00 & 75.00 & 89.54 & 79.84 & 78.00 \\
\hline April & 85.47 & 89.00 & 91.00 & 98.12 & 93.27 & 90.64 \\
\hline May & 101.05 & 98.00 & 109.00 & 102.59 & 96.12 & 95.18 \\
\hline June & 109.48 & 103.00 & 108.00 & 101.22 & 104.75 & 98.88 \\
\hline July & 120.26 & 105.00 & 111.00 & 102.93 & 113.79 & 105.2 \\
\hline August & 119.13 & 105.00 & 108.00 & 104.72 & 117.3 & 105.9 \\
\hline September & 118.95 & 113.00 & 114.00 & 104.46 & 114.33 & 111.05 \\
\hline October & 122.57 & 120.00 & 120.00 & 107.35 & 132.65 & 122.05 \\
\hline November & 121.34 & 132.00 & 120.00 & 112.86 & 121.11 & 129.61 \\
\hline December & 93.00 & 107.00 & 108.00 & 107.47 & 81.7 & 106.46 \\
\hline
\end{tabular}

has shown significant negative correlation in all the markets. The positive correlation coefficients shown in some of the markets in some years were found to be non significant. The results are in agreement with the study conducted solely in Agra market by Singh et al. (2017).

The seasonal variation indices (Table 3) clearly depict an inverse relation between the prices and arrivals of potato during the year. The wide seasonal fluctuation in arrivals has consequential unfavorable impact on prices in regulated market over different months of the year. The huge quantity of arrivals during post harvest months of the year lead to the decline in prices (Dhakre and Bhattachariya, 2014). As the harvesting season comes to an end the excess produce stored in the cold storages released in the market at reasonable prices from the months of July to November. 
It can be clearly seen from Figs. 1 to 6 that prices of potato are usually high during the months of October to December and starts declining till April which is in par with the post harvest period of the crop.

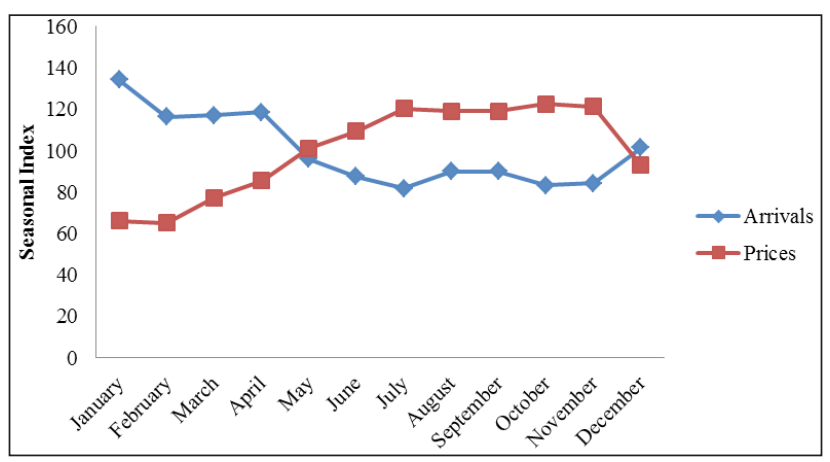

Fig. 1: Seasonal Indices of arrivals and prices of potato in Agra market from 2005 through 2014

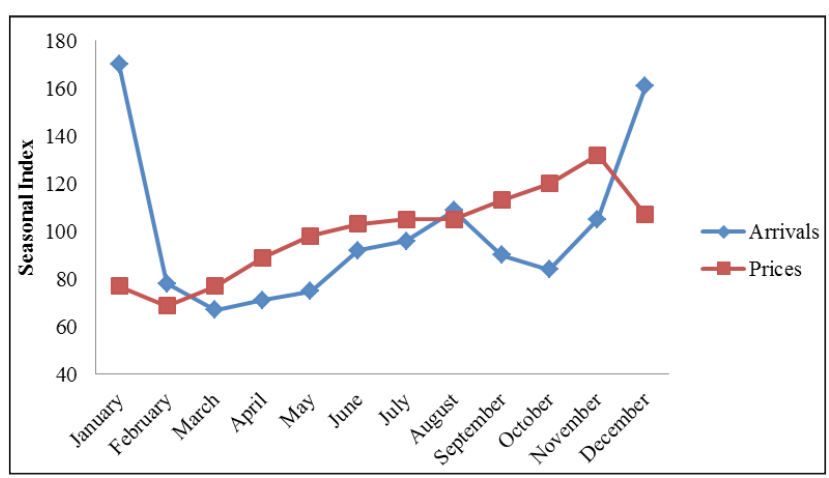

Fig. 2: Seasonal Indices of arrivals and prices of potato in Patna market from 2005 through 2014

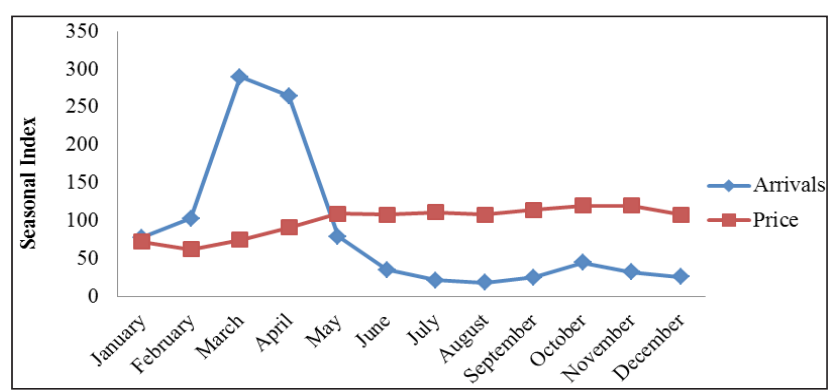

Fig. 3: Seasonal Indices of arrivals and prices of potato in Burdwan market from 2005 through 2014

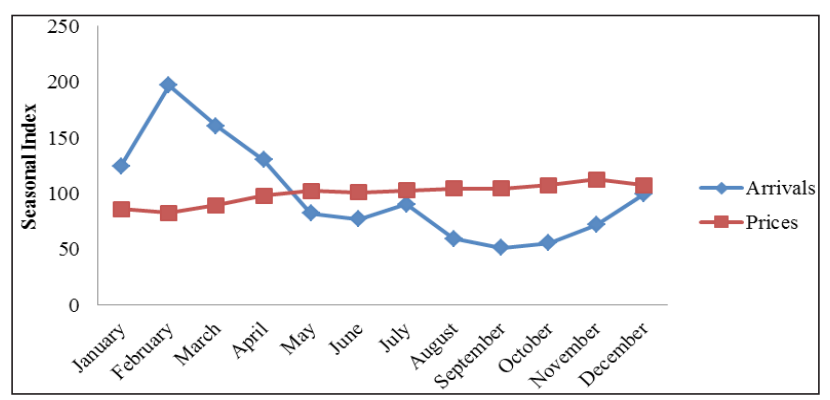

Fig. 4: Seasonal Indices of arrivals and prices of potato in Indore market from 2005 through 2014

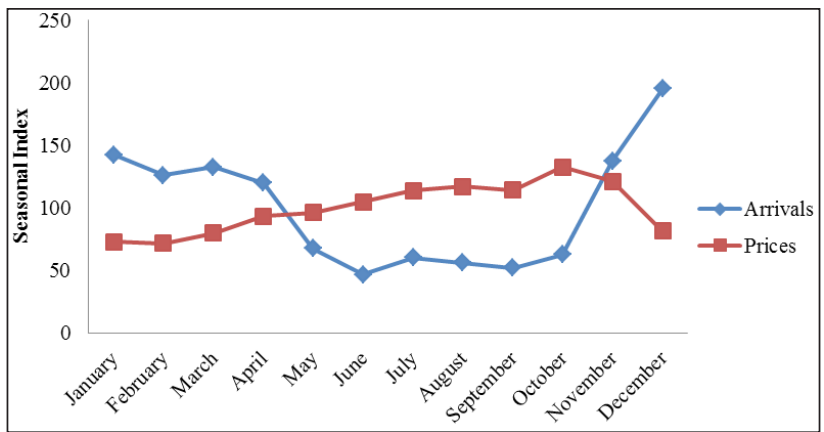

Fig. 5: Seasonal Indices of arrivals and prices of potato in Jalandhar market from 2005 through 2014

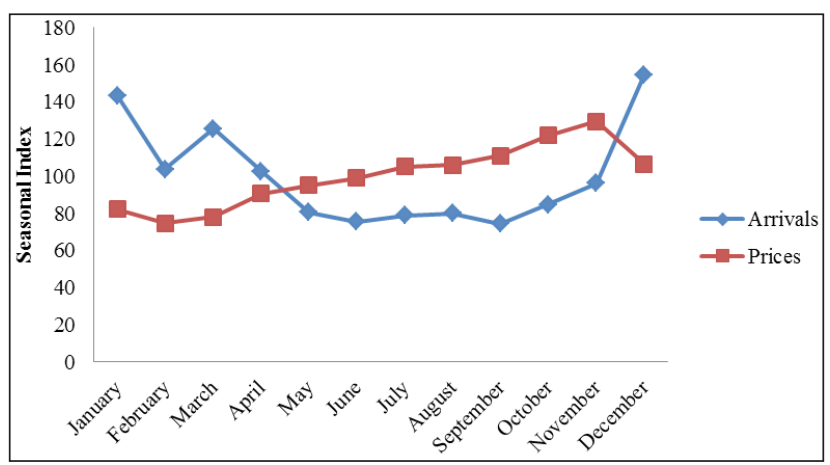

Fig. 6: Seasonal Indices of arrivals and prices of potato in Ahmadabad market from 2005 through 2014

The results of the analysis of factors affecting the potato prices for all the six markets taken together are presented in table 4 . It can be observed that the results area in par with the results obtained separately for each market. Potato prices showed a negative relation with the total arrivals and positive relation with the future prices and price lag. The regression coefficient of total arrivals was found to be -0.008 significant at 1 per cent level. The elasticity of prices with respect to the total arrivals was found to be -0.01 indicating that 1 per cent change in total arrivals would decrease the price by 0.01 per cent at all India level. The regression coefficient of production was found to be -0.0002 . The elasticity of prices with respect to production was found to be -0.15 , i.e., 1 per cent change in total production would decrease the price by 0.15 per cent The regression coefficient for future prices was found to be 0.30 significant at 1 per cent level indicating a positive relationship of market prices and future prices. The elasticity of market prices with respect to future prices was found to be 0.15 indicating that 1 per cent increase in future price would increase the market prices by 0.15 per cent. Similarly, a positive relation was established between the market price 
Table 4: Factors affecting prices of potato in major markets in India

\begin{tabular}{|c|c|c|c|c|c|c|c|c|c|c|}
\hline \multicolumn{2}{|c|}{$\begin{array}{l}\text { Dependent variable: } \\
\text { Current Prices }\end{array}$} & \multicolumn{9}{|c|}{ Independent variables } \\
\hline \multirow[b]{2}{*}{ Market } & \multirow[b]{2}{*}{ Intercept } & \multicolumn{4}{|l|}{ Coefficients } & \multicolumn{4}{|c|}{ Elasticity } & \multirow[b]{2}{*}{$\mathbf{R}^{2}$} \\
\hline & & Arrivals & Production & $\begin{array}{l}\text { Future } \\
\text { Prices }\end{array}$ & $\begin{array}{l}\text { Lagged } \\
\text { Price }\end{array}$ & Arrivals & Production & $\begin{array}{l}\text { Future } \\
\text { Prices }\end{array}$ & Price lag & \\
\hline \multirow[t]{2}{*}{ Agra } & 710.67 & $-0.01^{* * *}$ & -0.0002 & $0.41^{* * *}$ & $0.08^{* * *}$ & -0.08 & -0.41 & 0.47 & 0.72 & 0.89 \\
\hline & & $(0.01)$ & & $(0.05)$ & $(0.05)$ & & & & & \\
\hline \multirow[t]{2}{*}{ Patna } & -97.71 & $-0.35^{* * *}$ & -0.007 & $0.36^{* * *}$ & $0.73^{* * *}$ & -0.06 & -5.75 & 0.36 & 0.71 & 0.85 \\
\hline & & $(0.17)$ & & $(0.07)$ & $(0.03)$ & & & & & \\
\hline \multirow[t]{2}{*}{ Burdwan } & -335.19 & $-0.02^{* * *}$ & -0.0004 & $4.42^{* * *}$ & $6.14^{* * *}$ & -0.02 & -0.54 & 0.41 & 0.59 & 0.85 \\
\hline & & $(0.01)$ & & $(0.74)$ & $(0.63)$ & & & & & \\
\hline \multirow[t]{2}{*}{ Indore } & 1102.78 & $-0.05^{* * *}$ & -0.001 & $4.16^{* * *}$ & $0.43^{* * *}$ & -0.04 & -0.19 & 4.62 & 0.42 & 0.72 \\
\hline & & $(0.03)$ & & $(0.59)$ & $(0.07)$ & & & & & \\
\hline \multirow[t]{2}{*}{ Jalandar } & 503.91 & $-0.17^{* * *}$ & -0.004 & $0.22^{* * *}$ & $0.66^{* * *}$ & -0.11 & -1.40 & 0.35 & 0.65 & 0.78 \\
\hline & & $(0.04)$ & & $(0.04)$ & $(0.06)$ & & & & & \\
\hline \multirow[t]{2}{*}{ Ahmadabad } & 1395.68 & $-0.08^{* * *}$ & -0.002 & $0.30^{* * *}$ & $0.74^{* * *}$ & -0.14 & -0.33 & 0.25 & 0.74 & 0.79 \\
\hline & & $(0.03)$ & & $(0.07)$ & $(0.06)$ & & & & & \\
\hline \multirow[t]{2}{*}{ Total } & -421.33 & -0.008 & -0.0002 & 0.30 & 0.76 & -0.01 & -0.15 & 0.33 & 0.70 & 0.83 \\
\hline & & $(0.003)$ & & $(0.02)$ & $(0.02)$ & & & & & \\
\hline
\end{tabular}

***-significant at $1 \%$ level $^{* *}$-significant at $5 \%,{ }^{*}$-significant at $10 \%$.

and lagged prices with a regression coefficient of 0.76 . The elasticity of prices with respect to the lagged prices was found to be 0.70 indicating that one per cent increase in lagged prices would increase the market prices by 0.70 per cent. The coefficient of multiple regression was found to be 0.83 , indicating that 83 per cent of total variation in price of potato was explained by the arrivals, future prices and lagged prices.

There are also other factors like pest and disease attacks, weather irregularities, marketing aspects like transportation, storage, inadequate and costly cold chain facilities which affect the prices of potato. We know that about $90 \%$ of potato in India is produced in rabi season hence storage plays an important role in distributing supply over the remaining months of the year. Shortage of cold storage space in many states of India and erratic electricity supply create problems for potato marketing.

\section{CONCLUSION}

The price of agricultural commodities form the basis of income to the producers to allocate the resources in the marketing activities and allocation of goods and services among the prospective buyers and thus is the deciding factor of growth of a particular crop in the country. The present study examined the behavior of prices and arrivals of potato in major markets of the country. There is huge inter-year and intra-year instability in prices of potato. Production of potato and the seasonality in production are the two important factors affecting the same. Price discovery of potato is a complex process and is affected by a number of factors like production, total arrivals, lagged price, future prices, which have been quantified here and other factors like transportation, storage, weather uncertainties and pests and disease attack. Unexpected natural calamities and pests and diseases and frost have at times caused sudden drop in production of the crop in some state leading to higher prices. These higher prices induce the potato growers to increase the area under potato next year resulting in the increased production and arrivals leading to glut in the market and sharp decline in prices. Thus cobweb type demand supply cycle is prevalent in the potato production and marketing system in the country which bring violent fluctuations in potato prices and at the same time have serious political implications. Policy makers should emphasize on price stabilization strategies to safeguard the interest of all stake holders associated with the potato industry. 


\section{REFERENCES}

Dhakre, D.S. and Bhattacharya, D. 2014. Price behavior of potato in Agra market -A statistical analysis. Ind. Res. J. Ext. Edu., 14: 23-26.

Indiastat. 2019. Statistical da0074abase. From http://www. indiastat.com/agriculture/2/stats.aspx on 13-10-2019
Kumar, V., Sharma, H.R. and Sharma, R.K. 2006. Market arrivals and price behavior of potato: A study of four metropolitan markets. Ind. J. Agril. Mktng., 20: 78-89

Singh, D.K., Pynbianglang, K. and Pandey, N.K. 2017. Market Arrival and Price behaviour of Potato in Agra district of Uttar Pradesh. Economic Affairs, 62(2): 341. 
